УДК 63.3 (2)M-484

07.00.00 Исторические науки

МИФЫ И РЕАЛИИ РЕВОЛЮЦИЙ 1917 ГОДА

Мельситов Виктор Васильевич

Сергиенко Нина Леонидовна

Кубанский государственный технологический университет

350072, Российская Федерачия, г. Краснодар, ул.

Московская, 2

электронная почта: melsitov@ kubstu.ru

2017 год объявлен годом «100-летия Великой российской революции» или как еще её называют «Великой Русской революции». Таков посыл был дан в Послании Президента нашей страны В.В. Путина Федеральному Собранию РФ. Авторы в своей статье справедливо и аргументировано отмечают, что если Февральская буржуазная революция, несмотря на целый ряд объективных причин, всё-таки была верхушечным, дворцовым переворотом, то Октябрь 1917 года был именно революцией, а не каким-то большевистским заговором. Почему революция, а не переворот. Авторы доказывают и убеждают читателя, что это по своей сути была межформационная социалистическая революция, которая кардинально поменяла общественный строй и форму собственности. В статье доказывается, что дворцовый переворот, совершенный в Феврале и приведший к власти «политиков во фраках», в силу их бездействия и неумелости в политическом руководстве страны привел к победе Октября 1917 года. Ни один животрепещущий вопрос: о войне, о мире, о земле, о фабриках и заводах, о форме государственного устройства, Временным правительством не был разрешен. Поэтому в силу объективных и субъективных причин грянула победа Великой Октябрьской социалистической революции

КЛючевЫе слова: ФЕВРАЛЬСКАЯ БУРЖУАЗНАЯ РЕВОЛЮЦИЯ, ВЕЛИКАЯ ОКТЯБРЬСКАЯ

СОЦИАЛИСТИЧЕСКАЯ РЕВОЛЮЦИЯ, ПАРТИИ КАДЕТОВ, ЭСЕРОВ, БОЛЬШЕВИКОВ, ВРЕМЕННОЕ БУРЖУАЗНОЕ ПРАВИТЕЛЬСТВО, СОВЕТСКОЕ ПРАВИТЕЛЬСТВО
UDC 63.3 (2)M-484

History

\section{MYTHS AND REALITIES OF THE 1917 REVOLUTION}

Melsitov Viktor Vasilievich

Sergienko Nina Leonidovna

Kuban state technological university

2 Moscovskaya Street, Krasnodar, Russian

Federation, 350072

e-mail: melsitov@kubstu.ru

2017 was declared the year of the "100th anniversary of the Great Russian Revolution", or else it is called the "Great Russian Revolution". Such a message was given to the Address of the President of our country, V.V. Putin to the Federal Assembly of the Russian Federation. The authors in the article rightly and reasonably point out that if the February bourgeois revolution, despite a number of objective reasons, was still the apex, palace take-over, October of 1917 was precisely a revolution, and not some kind of Bolshevik conspiracy. Why a revolution, not a take-over? The authors prove and convince the reader that this was essentially an inter-information socialist revolution, which radically changed the social system and the form of ownership. The article proves that the palace coup, which took place in February and brought "politicians into dress coats" to power, led to the victory of October 1917 due to their inaction and incompetence in the country's political leadership. None of the exciting question: about the war, peace, land, factories and factories, the form of state structure, the Provisional Government was not allowed. Therefore, due to objective and subjective reasons, the victory of the Great October Socialist Revolution broke out

Keywords: FEBRUARY BOURGEOIS REVOLUTION, GREAT OCTOBER SOCIALIST

REVOLUTION, PARTIES OF THE CADETS, SOCIALIST-REVOLUTIONARIES, BOLSHEVIKS, PROVISIONAL GOVERNMENT OF THE BOURGEOISIE, SOVIET GOVERNMENT

Doi: 10.21515/1990-4665-132-103

Нынешний год объявлен юбилеем 100-летия «Великой российской революции» или «Великой Русской революции». Но с самого начала внедриния такой конструкции историки, публицисты, политики http://ej.kubagro.ru/2017/08/pdf/103.pdf 
столкнулись с большими трудностями как в определении понятий Октябрьская революция или Октябрьский переворот, так и тем, чем являлись события Февраля и Октября, и как они связаны между собой. При этом из разных лагерей исходит один и тот же посыл, данный Президентом страны в Послании Федеральному Собранию РФ: «Наступающий 2017 год - год столетия Февральской и Октябрьской революций. Это весомый повод ещё раз обратиться к причинам и самой природе революции в России. Не только для историков, учёных - российское общество нуждается в объективном, честном, глубоком анализе этих событий... Уверен, что... уроки истории нужны нам прежде всего для примирения, для укрепления общественного, политического, гражданского согласия, которого нам удалось сегодня достичь... Давайте будем помнить: мы единый народ, мы один народ, и Россия у нас одна».

Естественно, что эти слова, исполненные глубочайшего смысла, и которые должны разъяснить и объяснить не только ученые, но и общество в целом. Хочется надеяться, что благодаря русской толерантной истории, в отличие от европейской, для которой были характерны религиозные войны, суды инквизиции, погоня за ведьмами и прочие страшные деяния, наш народ сумеет дать правильные оценки событиям, случившиеся 100 лет назад.

И в то же время уже сегодня эти знаковые события, в нашей истории оцениваются целым рядом ученых и особенно, историков, очень легковесно и откровенно мифологизированно и пристрастно. Какие только мифы и бредни, фальшивки, клевета и нападки не изобретаются с целью опорочивания Ленина и большевиков, Октябрьской революции, всего советского прошлого. Вопреки установкам Президента В.В.Путина, часть научного сообщества и российских властей понимает юбилей революций в 2017 году как политическую акцию, непредсказуемую дезинтеграцией росийского общества. Хотя формально всё внешне со стороны властей http://ej.kubagro.ru/2017/08/pdf/103.pdf 
выглядит пристойно и хорошо. Так создан Юбилейный оргкомитет под председательством ректора МГИМО А. Торкунова, который выразил уверенность в том, что тема революции не должна стать поводом к раздраю и обострению в обществе. Примерно с теми же словами выступил и Минкульт страны объявивший, что цели акции - «подчеркнуть наше российское величие и значение для мира, а с другой стороны - усилить единение российского общества и обеспечить национальное примирение» [1].

Но если внимательно вглядеться в эти формулы, но мы увидим, что «эта тема не должна» породить раздрай и обострение, напротив, может вызвать раскол в обществе. Почему? Потому что названное мероприятие «100 лет Великой российской революции» является на самом деле юбилем двух революций - Февральской буржуазной и Октябрьской социолистической революций, которые нашли своё завершение в кровавой Гражданской войне, победосно закончившейся заветами Октября.

Сегодня совершенно ясно, что Февральские и Октябрьские события 1917 года, по своей социально-политической и экономической сути были, не просто противоположны, но и антоганистически непримиримы, поскольку исповедовали принципиально различные цели. У Февраля главный смысл - уничтожение самодержавия и установление буржуазного строя, у Великого Октября - свержение буржуазной демократии и установление господства общественной собственности на орудия и средства производства, торжества народовластия на социалистических началах.

Хотя ради справедливости следует отметить, что эти два эпохальных события довольно тесно связаны друг с другом, так как один процесс вырастал из предыдущего и был неразрывно связан с ним. Но если говорить о Февральской революции, то её большинство историков, особенно постсоветского периода, оценивают как дворцовый, http://ej.kubagro.ru/2017/08/pdf/103.pdf 
верхушечный, государственный переворот, который был организован частью радикальной и либеральной русской элиты, в первую очередь кадетами и октябристами, многие из которых были членами масонских ложь, в союзе с эсерами и меньшевиками, его осуществили.

Вместе с тем, если бы у буржуазных партий были только одни амбиции и самоувереннось в непогрешимости своих мечтаний о захвате власти, и не было бы никаких социально-политических объективных причин, то Февраль навряд ли бы состоялся.

И здесь хотелось бы привести несколько доводов в выше сказанный тезис. Так, начиная с конца 1916 года, и особенно в январе-феврале 1917 года, в стране накапливался «горючий материал». Так, пережив почти 900 дней бессмысленной для народов России войны, страна была изнурена немыслимыми человеческими потерями, почти полным развалом и падением экономики и производства, заброшенностью полей и недородом.. Для сравнения, в 1913 г. урожай достигал 6 млрд. пудов (около 100 млн. т.), то за 1916 г. собрали всего 2950 млн. пудов. Продовольственный кризис ужесточался день ото дня. Так, в Петрограде в январе муки оставалось на 10 дней, мяса не было вовсе [2]. А к февралю 1917 года Россия стояла на грани голода. С 15 января по 15 февраля запасы муки в Петрограде уменьшились с 1426 до 714 тыс. пудов, а 13 февраля градоначальник А.П. Балк сообщал, что за последнюю неделю подвоз муки составлял 5 тыс. пудов в день при норме в 60 тыс. пудов [3]. Таким образом, когда нынешние либеральные любители России «которую мы потеряли» стремяться доказать, что мол, на самом деле все было в порядке и с продовальствием и с экономикой, что якобы на пустом месте «в зажравшихся столицах» были спровоцированы беспорядки, не соответствуют реалиям.

Однако именно в эти два первых месяца 1917 года появляется в прессе такое понятие как «кризисы». Причем они разнообразны и http://ej.kubagro.ru/2017/08/pdf/103.pdf 
повсеместны. «В Твери...уже нет ни белого, ни черного хлеба. Нижегородские мельницы стоят. Даже Сибири коснулось тлетворное дыхание петроградской анемии. В Томске уже вводятся хлебные карточки...» - так писала совсем не Социал-демократическая газета «Русское слово» [2]. И таких примеров можно привести целые сотни, если не тысячи.

А тем временем, защитники и охранители самодержавного строя уверяли общество и государя императора, что в стране все хорошо и благополучно. Так 23 января 1917 года «Петроградские ведомости» утверждали: «Весьма утешительное, в сущности, состояние нашего народного хозяйства и обилие продовольственных запасов - это такой козырь в борьбе с доедающим свои запасы врагом, при котором на Руси должно наблюдаться очень крепкое настроение общества и народа. Народное настроение, и на самом деле, у нас твердое» [2]. Хотя на самом деле настроение народа и верхов к этому времени было абсолютно противоположное и прежде всего, рабочего класса. Стало очевидным, что монархия осталась «без руля и ветрил», а низы уже не могли и не хотели жить по - старому, как и не могли по - старому управлять верхи. Стремительно помимо выше сказанного, деградировали все государственные структуры, начиная с железнодорожного сообщения, снабжения страны продуктами, доставки на фронт боеприпасов и т.д. В стране, выражаясь ленинским языком, созрела революционная ситуация. А тем временем император Николай II полагает, что все в порядке и нет никаких оснований для беспокойства. Хотя представители оппозиции открыто предупреждали царя о надвигающейся на страну трагедии. Приведем один такой характерный эпизод на эту тему. Так, в первые дни февраля между императором и председателем IV-й Государственной Думы Михаилом Родзянко состоялся такой разговор: «Я Вас предупреждаю, заявил Родзянко, - я убежден, что не пройдет и трех недель, как вспыхнет http://ej.kubagro.ru/2017/08/pdf/103.pdf 
такая революция, которая сметёт и Вас, и Вы уже не будете царствовать». На что царь спросил: «Откуда Вы это берете?». «Из всех обстоятельств, как они складываются» - ответил Родзенко. «Ну, Бог даст...» - промолвил царь. «Бог ничего не даст. Революция неминуема» - ответил председатель Думы [2]. И меньше, чем через две недели революция грянула.

Теперь несколько тезисов о том, что якобы разразившаяся, в феврале 1917 года революция была полнейшей неожиданностью и внезапностью и о якобы непричастности к ней большевистской партии как организованной политической силы. Что же касается самого Ленина, то он будто бы «проспал» это событие. В подтверждение такой позиции авторы приводят его слова из «Доклада о революции 1905 года», написанного в январе 1917 года, что «мы старики», может быть, не доживем до решающих битв революции и на его слова из письма Инессе Арманд от 13 марта: «Из России нет ничего, даже писем!» Но цитируя этот доклад авторы такой версии, не упоминают, сделанную Лениным еще в декабре 1916 г констатацию высокой вероятности буржуазной револиции в России, в связи с возможным заключением сепаратного мира между российским императором и немецким кайзером и точным предсказанием ключевых фигур будущего Временного правительства «При теперешнем состоянии России её правительством могли бы тогда оказаться Милюков с Гучковым или Милюков с Керенским» [4].

Теперь о том, «причастны» или «непричастны» были большевики к февральской революции. Несмотря на то, что часть ЦК РСДП(б) во время войны были заграницей, а другая находилась в ссылках и тюрьмах царской России, в Петрограде действовало Русское бюро ЦК во главе с членом ЦК А.Г. Шляпниковым, который всю войну обеспечивал постоянную связь с Лениным и заграничной частью партии. Ясно, что это взаимодействие давалось нелегко, но оно было. Все дни революции с 23 по 28 февраля большевики были на стороне демонстрантов и вместе с другими http://ej.kubagro.ru/2017/08/pdf/103.pdf 
оппозиционными партиями, активно участвовали в этих событиях. Поэтому не случайно 27 февраля на первом заседании Петроградского Совета, несмотря на его эсеро-меньшивистское большинство, в Исполком были избраны большевики А.Г. Шляпников и П.Л.Залуцкий, что свидетельствует о роли партии в происшедшей революции.

И вместе с тем, конечно, не следует ни преуменьшить, не преувеличить роль РСДП(б) в этой революции. Заканчивая разговор, что было на самом деле в февральские дни 1917 года, мы хотим еще раз подвердить слова сказанные о них в статье выше: конечно же это был верхушечный, государственный переворот, но имевший под собой реальные, объективные и субъективные причины для его осуществления. Но в отличие от Октября, именно в «февральском безумии 1917 года» коренятся те огромные беды и страдания, которые обрушились на нашу страну в XX веке, поскольку огромные амбиции и самоуверенность бывших лидеров буржуазно-либеральной оппозиции после захвата ими государственной власти, сменилась полнейшей беспомощностью и растерянностью в практических делах. Наши российские либералы, истратив всю свою энергию и силы на борьбу с прогнившим царским режимом, в условиях его распада оказались совершенно непреспособленными и негодными людьми к государственной созидательной деятельности. Как совершенно справедливо заметил А.Лубков, что февраль 1917 года имел «...тяжелейшие последствия для России, вынужденной до конца испить горькую чашу торжествующей революции. К счастью, потом большевики смогли собрать в горниле кровавой Гражданской войны растерзанную историческую Россию и предложить ей «советский проект», истинный смысл, величие и предназначение которого многим непонятны до сих пор» [5].

Хотим мы того или не хотим, но при всей необъективности и предвзятости в оценке Октябрьской революции 1917 года, сегодня все http://ej.kubagro.ru/2017/08/pdf/103.pdf 
более отчетливее высвечивается тот факт, что по своим масштабам Октябрь стал всемирно-историческим событием, равных которому не было в истории человечества.

Почему Октябрь произошел так быстро, всего через восемь месяцев после победы Февральской революции. Сегодня даже околоисторическая публицистика согласна с тем, что это случилось в первую очередь в силу объективных исторических причин и полной политической импотенцией Временного буржуазного правительства. Как уже отмечалось, либеральные деятели, эти «революционеры во фраках», продуманным натиском отстранили царя от власти, и один на один остались с русским народом, а главное, с теми нерешенными проблемами, которые ослабили власть императора Николая II и сделали его свержение практически легким. Но эти «революционеры во фраках» оказались мало профпригодными к решению задач, связанных с госуправлением. И результат восьмимесячного правления буржуазии стал налицо: в отличие от экономики стоящей на краю пропасти перед февралем, получили от новых людей во власти такие показатели социально-экономического порядка, которые оказались в крутом пике. Все стало намного хуже: и финансы, снабжение продовольствием, инфляция и рост цен превысили все допустимые нормы. Временное правительство кормило народ обещаниями, не были решены ни рабочий, ни аграрные, ни национальный вопросы. Все более усиливались и культурно - циливизационные противоречия между победившей буржуазной «верхушкой» и обманутым, нищаюшим народом.

Главный вопрос любой революции - это вопрос о власти, но он тоже не был решен. Постоянно переносилось или откладывалось Учредительное собрание, которое должно было решить этот вопрос. Наконец не был решен вопрос о войне. В результате в обществе резко возросла социальная напряженность, которая к осени 1917 года превысила уровень периода http://ej.kubagro.ru/2017/08/pdf/103.pdf 
свержения монархии. Народные массы, недовольные Временным правительством создают свои собственные формы объединений в лице профсоюзов и Советов рабочих, крестьянских и солдатских депутатов и других объединений, которые неподконтрольны Временному правительству. Россия становится все более народной, и на смену февральской приходит Красная революция, к власти приходит Ленин и большевики.

Придя к власти, большевистское правительство все разрушительные процессы, вырвавшиеся в феврале 1917 года, переводит в созидательное, конструктивное начало. Причем надо отметить тот факт, что стартовые условия, в которых начинали большевики свою созидательную деятельность, были несоизмеримо хуже тех, которые получила либеральная буржуазия в феврале. Большевики начали с решения тех вопросов, которые не решались ни царским режимом, ни Временным правительством. Ленин и большевистская партия подобно Петру I поставили на дыбы Россию, свернули на путь постепенного выхода из катастрофы. Завоевания Великого октября сказались на судьбах всего мира и стали подражанием для всей планеты, даже после того, как исчез с карты мира СССР и мировая система социализма.

Один из главных уроков Октября 1917 года заключался в том, что Ленин и большевики, придя к власти, сумели убедить народные массы в том, что именно они и только они являются носителями и защитниками целостности и независимости России. Вот как писал по этому поводу главком вооруженных сил коалиционной Уфимской директории, участник антибольшевистского подполья генерал В.Г.Болдырев: «Живой и понятный лозунг, умело брошенный большевиками, имеющий конечной целью объединение России и сохранение её целостности, сам собой поднимает народ и заставляет его браться за оружие. А тот же призыв за 
«единую и неделимую» в устах вождей антисоветского движения оставался в большинстве случаев немым для широких масс населения» [6].

В конечном счете, именно победе Великого Октября мы обязаны триумфу нашей Победы в 1945 году над фашистской Германией, созданию ядерного щита, завоеванию космического пространства и других достижений. Поэтому как бы не пытались те или иные фальсикаторские силы на историческом фронте, в политике или в публицистике создать мифы или мифологемы, что Октябрьская революция, - всего-навсего рядовое событие XX века, которая якобы ничего не дала и ни принесла, кроме потоков крови, хаоса и бесмысленных жертв, ничего у них не получится. Факты упрямая вещь и никуда от них не уйдешь. И, тем не менее, даже из высоких правительственных кругов, подобного рода к сожалению, суждения исходят. Так, в сентябре 2016 года глава правительства РФ Д.А. Медведев дал следующую установку для интерпретации Октября 1917 года: «Эта революция - очевидный пример того, как с утратой стабильности были, по сути, разрушены основы экономики и на долгие годы утрачены перспективы экономического роста» [1].

Таким образом, если хотите, вольно или невольно задан соответствующий вектор в освещении этого эпохального события. Хотя рядом с такой установкой из стен научного совета при Совете безопасности РФ выходит, если так можно сказать, директива о том, что необходимо в течение 2017 года «противостоять попыткам намеренного искажения этого и других важнейших периодов в российской истории» [1]. Будем надеется, что такой подход возобладает и никакого искажения и фальсификаций Октября 1917 года не будет.

\section{Литература}

1. Литературная газета 15-21 февраля 2017 г. № 6

2. Советская Россия. 24 января 2017 г. 
3. Советская Россия. 7 февраля 2017 г.

4. В.И. Ленин ПСС. Т. 30 с. 243

5. Литературная газета 30 ноября - 6 декабря 2016 г. № 47

6. Литературная газета 18-24 января 2017 г. №1

\section{References}

1. Literaturnaya gazeta $15-21$ Fevralya 2017 № 6

2. Sovetskaya Rossiya. 24 Janvarya 2017

3. Sovetskaya Rossiya. 7 Fevralya 2017

4. V.I.Lenin PPS. T.30 s. 243

5. Literaturnaya gazeta 30 Noyabrya- 6 Dekabrya 2016 № 47

6. Литературная газета 18-24 Janvarya 2017 №1 